\title{
ÁLVARO CUNQUEIRO, JOSÉ J. VEIGA E A LITERATURA FANTÁSTICA
}

\section{Regina Zilberman \\ UFRGS}

doi:10.17075/mucnoc.2014.003 

Forcadela, M. / T. López / D. Vilavedra (coords.) (2014): Mil e un cunqueiros. Novas olladas para un centenario, Santiago de Compostela, Consello da Cultura Galega. doi:10.17075/mucnoc.2014. pp. 69-88

\section{O FANTÁSTICO E O ESTRANHO}

No início dos anos 70, do século xx, Tzvetan Todorov (1939), em Introdução à literatura fantástica, procurou estabelecer as características de uma vertente da produção literária que, na ocasião, inquietava os estudiosos. A década anterior assistira ao esgotamento dos modelos experimentalistas da vanguarda ocidental, bem como à ascensão do chamado Realismo Mágico, praticado por latino-americanos, a exemplo do colombiano Gabriel García Marques (1927) e do mexicano Juan Rulfo (1917-1986), entre tantos nomes que podem ser lembrados: o guatemalteco Miguel Angel Asturias (1899-1974), premiado com o Nobel, o peruano José Maria Arguedas (1911-1969) ou o paraguaio Augusto Roa Bastos (1917-2005), o prematuramente desaparecido Manuel Scorza (1928-1983). O cubano Alejo Carpentier (1904-1980) já valorizara o pendor da produção ficcional da América Latina na direção do Real Maravilhoso, designação que mescla duas qualidades aparentemente inconciliáveis, mas que se particularizaria no contexto da arte do território situado abaixo do Rio Grande.

Todorov, em seu livro, configura três categorias básicas, a partir das quais estabelece sua tipologia: o estranho, o fantástico e o maravilhoso. As diferenças dependem do modo como uma obra de ficção expóe o «acontecimento extraordinário», em princípio inexplicável, que a posiciona —ou não— no âmbito da literatura fantástica. $\mathrm{O}$ fato incomum, segundo Todorov, produz necessariamente uma "hesitação», experimentada tanto pelas criaturas ficcionais como pelo leitor. A partir daí, patenteiam-se três possibilidades, determinando as distinções entre as categorias básicas:

- $\mathrm{O}$ «acontecimento extraordinário» explica-se racionalmente, de que emerge o estranho.

- O «acontecimento extraordinário» não perde o caráter de sobrenaturalidade, mas é aceito conforme a lógica reinante entre as figuras ficcionais; neste caso, como ocorre entre contos de fadas e narrativas populares, vigora o maravilhoso. 
- A terceira alternativa não se decide por nenhum dos dois caminhos. Conforme Todorov, «há um fenômeno estranho que podemos explicar de duas maneiras, por tipos de causas naturais e sobrenaturais. A possibilidade de hesitar entre as duas cria o efeito fantástico» (p. 30) —eis a autêntica literatura fantástica ${ }^{1}$.

A associação entre o maravilhoso e o conto de fadas não é arbitrária. Data do mesmo período a tradução, para o francês, da Morfologia do conto, de Vladimir Propp (1895-1970), que lida com narrativas populares russas, doravante conhecidas também como "contos maravilhosos», conforme é designado, na edição brasileira, o material com que trabalha o pesquisador soviético ${ }^{2}$.

Por sua vez, o «estranho» tinha sido objeto de investigação de Sigmund Freud (1856-1939) em direção diferente e mais complexa da que estuda Todorov. O ensaio, de 1919, questiona o significado do unheimlich, aquele que é assustador, provocando medo e horror, uma espécie de terror sem a piedade à que se refere Aristóteles (384-322 a. C.), para explicar, na Poética, a singularidade da catarse ${ }^{3}$.

Freud toma como ponto de partida o vocábulo — unheimlich — que, em alemão, designa o estranho. Unheimlich provém de heimlich, acrescido da partícula negativa —un. Por sua vez, o adjetivo procede de Heim, casa ou lar, apontando, pois, para o familiar. Assim, o estranho nasce do desconforto com o familiar, ou, colocando nos seus termos, "o estranho é aquela categoria do assustador que remete ao que é conhecido, de velho, e há muito familiar» (p. 238) ${ }^{4}$. A metamorfose, de Franz Kafka (1883-1924), de 1915, contemporânea, pois, às reflexóes de Freud, talvez explique o procedimento: o protagonista da novela, Gregor Samsa, caixeiro-viajante responsável pelo sustento econômico de seus pais e de sua irmã, acorda um dia "transformado num gigantesco inseto» 5 . No seio do universo doméstico, instala-se o estranho, que, por inesperado, inexplicável e irreversível, provoca alteraçóes no modo de vida dos envolvidos na existência de Samsa.

1 As citaçôes provêm de: Tzvetan Todorov: Introduction à la littérature fantastique. Seuil: Paris, 1970. A propósito da tipologia sugerida por Tzvetan Todorov, v. José Paulo Paes: «As dimensões do fantástico». In: Gregos \& Baianos. São Paulo: Brasiliense, 1985.

2 Cf. Vladimir Propp: Morfologia do conto maravilhoso. Rio de Janeiro: Forense Universitária, 2006.

3 Cf. Aristóteles: Poética. Trad. Eudoro de Souza. Porto Alegre: Globo, 1966.

4 As citaçóes provêm de: Sigmund Freud: «O estranho». In: Uma neurose infantil e outros trabalhos. Trad. Eudoro Augusto Macieira de Souza. Rio de Janeiro: Imago, 1996. (Edição Standard Brasileira das Obras Psicológicas Completas de Sigmund Freud, v. XVII).

5 Franz Kafka: A metamorfose. Trad. Modesto Carone. São Paulo: Companhia das Letras, 1997. p. 1. 
O psicanalista austríaco chama a atenção para um dos temas mais representativos do estranho: «a sensação, em seu mais alto grau, em relação à morte e aos cadáveres, ao retorno dos mortos e a espíritos e fantasmas» (p. 258). Observa que, em muitas línguas, a expressão alemã «uma casa unheimlich» só pode ser traduzida por «uma casa assombrada» (p. 258), sugestiva da associação entre a morte e o sobrenatural. Freud explica o significado da associação:

Dificilmente existe outra questão, no entanto, em que as nossas idéias e sentimentos tenham mudado tâo pouco desde os primórdios dos tempos, e na qual formas rejeitadas tenham sido tão completamente preservadas sob escasso disfarce, como a nossa relação com a morte. Duas coisas contam para o nosso conservadorismo: a força da nossa reaçáo emocional original à morte e a insuficiência do nosso conhecimento científico a respeito dela. A biologia não conseguiu ainda responder se a morte é o destino inevitável de todo ser vivo ou se é apenas um evento regular, mas ainda assim talvez evitável, da vida. [...] Uma vez que quase todos nós ainda pensamos como selvagens acerca desse tópico, não é motivo para surpresa o fato de que o primitivo medo da morte é ainda tão intenso dentro de nós e está sempre pronto a vir à superfície por qualquer provocação. (p. 259).

A partir desse aspecto, Freud propóe a equação que explica o significado do estranho e, sobretudo, o medo suscitado por ele: o estranho abriga algo reprimido, que retorna à consciência naquele formato «desfamiliar». Assim, o «estranho não é nada novo ou alheio, porém algo que é familiar e há muito estabelecido na mente, e que somente se alienou desta através do processo da repressão» (p. 258). Mais adiante, reitera: «o estranho provém de algo familiar que foi reprimido» (p. 264).

Dentre os sentimentos reprimidos, Freud destaca o que parece mais próprio ao estranho —o complexo de castração, elencado na companhia de outras expressóes características do estranho:

Agora temos apenas algumas observaçóes a acrescentar — pois o animismo, a magia e a bruxaria, a onipotência dos pensamentos, a atitude de homem para com a morte, a repetição involuntária e o complexo de castração compreendem praticamente todos os fatores que transformam algo assustador em algo estranho. (p. 260).

Freud e Todorov não percorrem o mesmo caminho quando refletem sobre o fantástico ou o estranho. Para o primeiro, o estranho pode ter uma causa, mas não uma explicação; representado, ele toma a forma de uma distorção, que pode 
se configurar em figuras e situaçóes sobrenaturais, sendo essas, da sua parte, sintomas de um sentimento reprimido, que, ao retornar, assusta, espanta ou aterroriza. De todo modo, a normalidade — resumida na noção de familiaridade — se desestrutura, alterando sua natureza e propondo alternativas de rumos a tomar.

As obras que se examinam refletem sobre esses rumos e suas causas.

\section{OS MORTOS ESPERAM}

Ao iniciarem-se As crônicas do sochantre, Charles Anne Guenolé Mathieu de Crozon é um jovem de 22 anos que reside em Pontivy, na Bretanha recriada pela imaginação de Álvaro Cunqueiro (1911-1981). Descende de família de estirpe, a quem fora concedido o privilégio de «correr com um pano verde pelas ruas de Rennes berrando que vinha El Rei, quando o Cristianíssimo escrevia que ia visitar a Bretanha, ainda que depois não viesse» (p. 11) ${ }^{6}$. Sua mãe morrera quando ele tinha onze anos, tendo sido educado por uma criada, que, na juventude, "vestida de homem» (p. 12), se alistara na artilharia real. Quando referido por outras personagens, o pai é chamado $\mathrm{O}$ Vesgo, alcunha que o identifica; mas não se interessa particularmente pela formação do filho, cuja profissão acaba por ser definida pela "artilheira», "quem determinou fazer músico a Charles Anne» (p. 12). Eleito o instrumento adequado ao rapaz —o «bombardino» ou «bombardão», isto é, o trombone de pistons_- escolhe para ele igualmente o local e tipo de trabalho a desempenhar: sochantre na Santa Colegial Capela, de Pontivy. É onde o leitor o encontra, ao começar a narrativa.

O estranho se instala desde a situação inicial da personagem, cujas opçôes decorrem de decisóes da andrógina criada, misto de mãe cuidadosa e de pai autoritário, já que assume a identidade militar, seja como artilheira, antes de trabalhar para a família De Crozon, seja por se empregar como guarda suíço do Papa, na Itália, após encaminhar Charles para uma atividade profissional. Porém, é o cenário bretão, desde a abertura do romance, que configura o ambiente sobrenatural, antecipando as expectativas quanto à ação a ser narrada: «Bretanha é uma terra

6 As citaçôes, reproduzidas em português, provêm de: Álvaro Cunqueiro: As cronicas do sochantre.

[Vigo], Galaxia, [1956]. 
muito apenedada pela banda do mar, porém, por onde se une a França, abre-se em amplas planícies, vales estreitos e alegres outeiros. É terra muito viciosa de caminhos, porque nela, amém de gente natural de sobremundo, andam fáceis e muito vigilantes passageiros, gentes das soterradas alamedas, defuntos vespertinos, fantasmas, hostes cavaleiras, ânimas redimindo-se de obrigas; as mais delas, gentes falecidas às quais alguma peta não deixa sossego" (p. 9) —eis as palavras de abertura do prólogo, que traz consigo pelo menos duas situaçóes inusitadas ao espírito racionalista do leitor moderno:

a) Bretanha é considerada uma terra diferenciada, apartada da França, e não porção de seu território nacional.

Esse recuo é estratégico, pois confere autonomia ao local onde se passa a ação, impedindo que se estabeleça um paralelo, em termos de semelhança ou reprodução, entre a Bretanha de As crônicas do sochantre e a região que compóe a naçáo francesa. Por outro lado, permite a proposta de um outro paralelo, entre a Bretanha do romance e aquela das lendas medievais, mencionada, aliás, pelo narrador, no «Epílogo aos bretôes», adicionado por Álvaro Cunqueiro à tradução espanhola de seu livro.

Justificando a escolha daquela região para desempenhar o papel de espaço dos acontecimentos, o narrador chama a atenção, primeiramente, para as similaridades entre a Bretanha, conhecida por ele através das obras de autores como René de Chateaubriand (1768-1848) ou Villier de l'Isle Adam (1838-1889), entre outros, e sua terra galega natal, ambas povoadas por «fantasmas, bruxas, mendigos, santos e heróis». Depois, emenda: «não é alheio a isso o [fato] de que também se chamara Bretanha o país assombroso do rei Artur» (p. 188) ${ }^{7}$.

A ruptura com o realismo da representação se dá desde as páginas iniciais da obra, complementando-se, na versão em castelhano, pelos últimos parágrafos, quando se evidencia a conformação particular do cenário, resultante da combinação de experiências pessoais — «os campos e as cidades, os rios e os vaus, os caminhos e as ruínas, pintei-os do natural da minha terra, Galícia, sendo ambos, o bretão e o galego, reinos atlânticos, finisterras, semelhantes em flora e fauna, e províncias vagamente distantes» (p. 185)—, de leituras literárias e da imaginação.

7 As citaçôes, reproduzidas em português, provêm de: Álvaro Cunqueiro: Las crónicas del sochantre. 4. ed. Barcelona: Ediciones Destino, 1989. p. 188. 
b) Nesse território, muito particular, convivem seres vivos e defuntos, fantasmas e almas penadas.

Ao indicar, desde a abertura, o horizonte sobrenatural do espaço onde transcorre a ação do romance, define-se a filiação desse, ao mesmo tempo antecipando o conteúdo da narrativa, quando assumem o protagonismo as almas penadas, conforme o narrador, características da Bretanha (e da Galícia, por tabela).

A esse universo assinalado pela sobrenaturalidade, encarada, contudo, sem espanto pelos habitantes do local, opóe-se, à primeira vista, a natureza e a história de Charles de Crozon, o jovem músico que se satisfaz com a execução do instrumento escolhido pela «artilheira». Contudo, sua rotina diária é abalada, primeiramente, pela luxúria, já que o atraem as formas físicas da viúva Clementina Marot, em casa de quem se hospeda:

Enquanto tocava a marcha no borbardino, olhando para a almofada, mais de uma vez veio-lhe à mente ao senhor sochantre a semelhança que tinha aquela com o proeminente peito de Madame Clementina, principalmente porque essa era muito dada a penteadores amarelos com borlas, e disso passou a imaginar que, do mesmo modo que o Colegial punha os joelhos na almofada, poderia ele pôr os seus nas manteigas de Madame Clementina, quando esta se abaixava para abotoar-lhe os botóezinhos de prata nas canelas. (p. 18-19).

Depois, pela excursão à que é obrigado a fazer, para tocar o bombardino no enterro do fidalgo de Quelven.

Acompanhar o enterro dos mortos em Pontivy consta das tarefas de Charles de Crozon. Participar das exéquias do fidalgo de Quelven interessa-lhe particularmente, já que herdará do falecido um pomar de maçãs, o que lhe possibilitará concretizar um de seus sonhos, o de tornar-se proprietário, para o que contribuem também as economias que acumula durante o exercício de sua função de trombonista.

É quando se dirige ao local do enterro que irrompem os acontecimentos capazes de alterarem a rotina diária. $\mathrm{O}$ estranho se instala, na medida em que o familiar não é mais reconhecido: o ambiente toma coloração fantasmagórica: «A rua pareceu muito longa ao sochantre, sempre seguindo a pouca luz do farolinho, e desconheceu-lhe o piso, e não sabia por onde andava. [...] Nunca névoa tal se vira em Pontivy» (p. 22) e De Crozon é de certo modo sequestrado pelos mortosvivos que o encaminham para a execução de seu concerto em outro local. 
É Mamers o Coxo quem o encaminha para a carroça onde se encontram as demais almas penadas: Clarina de Saint-Vaast; Jean Pleven, o escrivão enforcado de Dorne; Monsieur de Nancy, o verdugo de Lorena; o médico John Sabat, envenenador das fontes de Roma; Guy Parbleu, identificado pela luzinha que restou dele; e o aristocrata Coulaincourt de Bayeux, líder do grupo. A companhia, formada por «réprobos, fantasmas, enforcados e sombras» (p. 26), conforme resume Coulaincourt de Bayeux, dirige-se ao enterro do fidalgo de Quelven, que, tal como o grupo, não repousará em sua cova enquanto não pagar de alguma forma pelo crime que cometeu por ocasiáo de seu falecimento.

Eis o ponto que congrega a sobrenatural companhia: todos faleceram há algum tempo, mas suas mortes se deram quando praticavam algum tipo de delito: Madame de Saint-Vaast envenenava a irmã, Ana Eloísa, que lhe roubara o noivo, Pierre; o escrivão Jean Pleven, quando ambicionava adonar-se do tesouro de dois de seus clientes; Coulaincourt de Bayeux, por violador de crianças e estuprador; John Sabat, por planejar o envenenamento das fontes de Roma, o que o faria mais rico; Guy Parbleu, o órfão abandonado à roda das crianças e servo do demônio, que é flagrado roubando e, depois, queimado em praça pública; e o próprio fidalgo de Quelven, que morre por vingança do cão que envenenara.

A maioria dessas personagens causou inadvertidamente a própria destruição: Clarina, Pleven, Sabat e Quelven perdem a vida, quando acabar com outros. Da sua parte, mesmo os que são justiçados, como Bayeux, Monsieur de Nancy e Parbleu, não passam formalmente por um julgamento público, sendo sua morte fruto da reação intempestiva da população ou dos soldados. Este é, pois, um universo desregrado, entregue à violência e ao arbítrio dos indivíduos, competindo tão-somente ao sobrenatural algum tipo de regulação. Por isso, as personagens devem deambular de praça em praça com sua carroça, relatando em incontáveis ocasiôes a própria história e metamorfoseando-se diariamente, já que, à luz do sol têm carnadura, mas, à noite, com exceção de Parbleu, reduzem-se à sua carcaça: «fechando a noite, voltamos por seis horas à nossa condição de esqueletos» (p. 35). Essa condição é, por sua vez, temporária: «quando chegue a hora do descanso e em três anos esta tropa pousará em terra de vez» (p. 35), explica Bayeux a Charles.

É o que ocorre ao final da narrativa, quando De Crozon pode retornar à casa, reencontrando-a tal qual a deixara, embora o aspecto do moço se tivesse alterado 
muito: «Sentiu que alguém movimentava-se na cozinha, porém não quis entrar, por medo de que assustasse madame Clementina, ao não conhecê-lo com as barbas de três anos, que, enquanto andara com a hoste, não se barbeara» (p. 139). Mas a falta dele não havia sido percebida, já que outro fantasma, o do tio do cocheiro Mamers, tomara seu lugar. Encerrada a aventura, deve ter começado a narrativa dela, pois o narrador, nas primeiras páginas do romance, faz questão de destacar que as crônicas não são de sua autoria, tendo-as encontrado registradas em libretos de pele de coelho, dando conta dos eventos transcorridos entre 1793 e 1797 .

As crônicas não relatam unicamente as histórias dos fantasmas, matéria da segunda parte do livro. Entre a reprodução das pequenas biografias e o final, os singulares viajantes cruzam a Bretanha, partindo de Saint-Efflan na direção de Toul Galic. Durante o caminho, deparam-se com os conflitos entre chouans e republicanos, tomando a companhia de Coulaincourt de Bayeux o partido dos monarquistas. Alcançam Dinan, onde se inaugura o uso da guilhotina, instrumento de morte que muito agrada a Monsieur de Nancy, o verdugo de Lorena, dada sua eficiência e pureza. E chegam a Comfront, onde são confundidos com uma trupe de atores, aguardada na cidade para encenar Romeu e Julieta.

A hoste de cadáveres, recepcionada pelo prefeito da cidade, cumpre a função, recriando o texto, reproduzido na forma dramática no livro, já que a peça fora encontrada entre "os papéis do sochantre» (p. 121). Mas a apresentação acaba por ser bruscamente interrompida, já que anoitece, e os atores revelam sua faceta macabra, aparecendo na forma de esqueletos. $O$ público pensa deparar-se com os efeitos da peste e foge, ficando pela metade a exposição do drama que, da sua parte e sintomaticamente, exibe o final de uma guerra em Verona, bem como as expectativas, pela população, de que se superassem a fome e a pobreza reinantes no local.

Um último episódio completa a terceira parte: o fidalgo de Quelven, de aniversário, deseja visitar uma jovem de quem fora amante. $\mathrm{O}$ grupo hospeda-se na pousada Nova França, e o sochantre é incumbido de tocar o trombone para a Senhorita de Vitré, que pensará ouvir o concerto oferecido pelo aristocrata. A performance fracassa, pois Charles de Crozon embriaga-se, há brigas na hospedaria, e o incidente termina de modo frustrante para todos. 
O término das aventuras coincide com o retorno do sochantre, dando a supor que se completara o prazo de expiação dos mortos ambulantes. Sob esse aspecto, algum tipo de justiça se estabelece, já que suprime, ao menos parcialmente, as figuras criminosas do horizonte da vida cotidiana bretã.

A filiação da obra ao que Tvzetan Todorov designa como literatura fantástica se evidencia desde seu começo, como se observou antes ${ }^{8}$. Náo apenas se materializam eventos que fogem à normalidade, como eles supóem a hesitaçáo a que se refere o pesquisador búlgaro. No decorrer da narrativa, a hesitação não se explicita; porém, impóe-se ao final, quando Charles de Crozon percebe que sua ausência não havia sido registrada. A partir dessa situação, é lícito concluir que a aventura náo passara de um sonho, de que o rapaz desperta, retomando sua rotina. Afinal, os episódios que lhe dizem respeito iniciam pela manhã, quando, após o acordar e o desjejum, dirige-se à Capela de Pontivy para a homenagem fúnebre a Quelven. Quando regressa, é igualmente matina, cabendo apenas a Charles deixar partir o tio de Marman, que o substituíra no período. Além disso, conhecem-se os acontecimentos por intermédio dos escritos do próprio Charles de Crozon, o que posiciona o narrado sob o prisma da suspeita, pois os fatos podem ter acontecido ou serem tão-somente fruto da fantasia do instrumentista musical.

É por sutilmente sugerir que a novela ambienta-se em contexto onírico que se pode retornar às observaçóes de Sigmund Freud referentes ao estranho.

Em As crônicas do sochantre, o estranho igualmente relaciona-se à desfamiliarização, tal como propóe o psicanalista austríaco. Só que o estranho não decorre da presença do sobrenatural, já que este, a se crer no prólogo, é parte inerente do meio bretão. $\mathrm{O}$ estranho localiza-se no âmbito da desordem reinante, decorrente, sobretudo, do ambiente revolucionário experimentado, naquele momento, pela sociedade francesa, logo, na Bretanha. Essa apresenta-se como microcosmo daquela, expondo o enfraquecimento da justiça (é sintomática a cena em que Monsieur de Nancy decapita, sem qualquer motivação, a não ser seu gosto depravado de carrasco, o funcionário Toulet, que lhe ensinava o funcionamento da guilhotina), a imposição do arbítrio e da violência, a dominação dos mortos sobre os vivos.

8 A propósito, veja também Pilar Vázquez Cuesta: «Carta da Galiza. Álvaro Cunqueiro, precursor do “realismo mágico"». Revista Colóquio/Letras. N. 62. Jul. 1981, p. 72-75. 
A curta peça encenada pelos cadáveres insepultos exemplifica o tema: os amantes Romeu e Julieta não aparecem no palco, e a última assistente a se retirar da praça onde o texto é apresentado, a menina que lê uma carta, lamenta que «não havia Romeu» (p. 130). Em lugar do amor, o público se depara com as esperanças, pelo povo de Verona, de que a paz traga alimentos e riqueza, o que náo se concretiza, pois o drama é subitamente encerrado. Por sua vez, o término da encenação deve-se ao reconhecimento, pelo público, de que a peste avizinha-se, encarnada na carcaça dos atores.

O estranho coincide com a falta de ordem, pois na "Nova França», nome da taberna onde, por último, se instalam os insepultos, impera a bebedeira e a violência. É o mundo dos conflitos bélicos e da destruição que se expóe, exibido por meio de uma linguagem irônica, à moda das pinturas de Goya (como, por exemplo, «Fuzilamentos de 3 de maio de 1808») que abordam tema similar.

Não por acaso situando a ação do romance à época do Terror, As crônicas do sochantre revelam o terror da guerra e das revoluçôes que dividem uma nação ao meio. Mas o estilo não é o da denúncia ou o da polêmica, e sim o do humor e do sarcasmo, meio escolhido para desmontar imagens que, de outra maneira, mostrar-se-iam épicas e celebratórias.

Em meio a esse caos, faz-se a formação de Charles de Crozon. Que sua imaturidade, como quereria Freud, se deve à irresolução e repressão de sua sexualidade, indicam-no vários fatores: a indeterminação de gênero da "artilheira», que faz simultaneamente os papéis materno e paterno, indecisão que se materializa em sua androginia; a contemplação das formas femininas inalcançáveis, seja as da matrona Clementina Marot, seja as de Clarina de Saint-Vaast, esta em processo de decomposição, dado seu estado de morta ainda não enterrada. É preciso que essa mulher seja devolvida ao mundo subterrâneo para provavelmente Charles liberar sua sexualidade e suplantar suas inibiçóes diante do sexo oposto. Para tanto, o gênero feminino precisa aparecer na sua condição de estranheza ou Umheimlichkeit, caso contrário, ele não retornaria à normalidade após a peregrinação experimentada junto à hoste comandada por Coulaincourt de Bayeux.

As crônicas do sochantre relatam, assim, um ritual de passagem. E, como tal, apropriam-se de sua forma original, a narrativa do maravilhoso, como propóe 
Vladimir Propp 9 . É a trajetória do sochantre, pois, que oferece ao leitor um caminho para além da desordem e da desunião, caminho que depende de uma experiência do caos na direção de sua superação. Charles de Crozon contou com a oportunidade que Gregor Samsa, figura ficcional que igualmente ultrapassou o inferno, não recebeu, e foi capaz de transformá-la na aprendizagem que compartilhamos.

\section{INFÂNCIA SEM FUTURO}

José J. Veiga (1915-1999) publicou seu primeiro livro, Os cavalinhos de Platiplanto, em 1959. Desde os contos contidos nessa obra, até os últimos romances, como $O$ relógio Belizário, de 1995, o escritor definiu-se pela literatura fantástica. Entre um ponto de outro, lançou $A$ hora dos ruminantes (1966), A máquina extraviada (1967), Sombras de reis barbudos (1972), De jogos e festas (1980), Aquele mundo de Vasabarros (1982) e Torvelinho dia e noite (1985), além de narrativas dirigidas ao público infantojuvenil.

Sombras de reis barbudos coloca-se em ponto intermediário da carreira de ficcionista de José J. Veiga, constituindo um de seus livros mais conhecidos, pois, em 2011, alcançou a vigésima-oitava edição. O romance é narrado em primeira pessoa por Lucas, ou Lu, como é chamado por parentes e amigos. O jovem que, ao escrever o texto, parece atender ao pedido de sua máe, relata os acontecimentos experimentados pela cidade de Taitara após a chegada de Baltazar, tio do rapaz, com projetos de fundação de uma grande indústria. Após alguns percalços, instala-se a Companhia Melhoramentos de Taitara, administrada por Baltazar, com a assessoria, entre outras pessoas, de seu cunhado e pai do narrador.

O sucesso do empreendimento é bastante grande, e a cidade parece recompensada: a população é feliz, e Baltazar, um herói popular. Sobrevém, contudo, um golpe, e Baltazar é destituído da direção da empresa, tendo de abandonar a cidade. Mudanças profundas acontecem aos poucos: a fábrica atua de modo severamente repressor, dificultando a rotina dos cidadáos de Taitara, impondo

9 Cf. Vladimir J. Propp: Las raíces históricas del cuento. Trad. José Martín Arancíbia. Madrid: Fundamentos, 1974. 
várias proibiçóes e implementando uma milícia para controlar a vida pública. $\mathrm{O}$ pai de Lu, o narrador, adere à nova situação, destacando-se como policial, mas, diante do recrudescimento da repressáo, abre mão do poder e almeja mudar de trabalhado, projeto cancelado, pois é encarcerado pelos fiscais do sistema.

O narrador relata ao mesmo tempo o que ocorre a Baltazar, que, envelhecido e marginalizado, reside longe de Taitara e que, em dado momento, recebe a visita do sobrinho. O rapaz é hospedado pela esposa de Baltazar, Dulce, que o acolhe com carinho e até amor. Lu, contudo, retorna à sua terra e, diante do empobrecimento de sua família, procura e obtém emprego. A falência geral do município faz com que perca a posição, instalando-se a desesperança não apenas nele, mas na maioria de seus conterrâneos.

A situação não se altera até o final do romance; porém, dá-se um fenômeno inexplicável: todos, a começar por Lu e incluindo os fiscais da Companhia, veem, no céu, homens que, mesmo sem asas ou qualquer aparelho auxiliar, voam, gozando de incontrolável liberdade. Tentando interpretar os acontecimentos, $\mathrm{Lu}$ é informado por um professor, presente nas páginas finais da obra, que se trata de uma «alucinação coletiva» (p. 141) ${ }^{10}$, mas que tal reação não é um problema, e sim uma solução: corresponde ao remédio necessário a todos, até «aqueles [que estão] lá em cima» voltarem "para a festa dos reis barbudos» (p. 142).

As cenas finais do romance parecem as mais comprometidas com a literatura fantástica: os moradores de Taitara avistam, no céu, pessoas que voam, cena testemunhada inclusive pelos policiais. No entanto, um professor, portanto, um indivíduo ligado ao mundo do saber, qualifica de «alucinação coletiva» o comportamento dos cidadãos. Essa "alucinação coletiva», por sua vez, não é negativa, e sim positiva; além disso, aos homens-pássaros é atribuída uma peculiaridade: eles retornarão por ocasião da «festa dos reis barbudos», resposta sugestiva de que não apenas o professor enxerga os voadores, como explica seu aparecimento e retorno por meio de um enquadramento mágico.

A resposta do professor é sugestiva de outro aspecto: ele também é vítima da "alucinação coletiva», o que relativiza sua explicação. Instala-se, dessa maneira, a «hesitação» considerada vital, segundo Todorov, para a qualificação da obra como

10 As citaçôes provêm de: José J. Veiga: Sombras de reis barbudos. 28. ed. Rio de Janeiro: Bertrand Brasil. 2011. 
fantástica. Configurando a natureza pouco convincente da explicação, essa colabora para a indefinição do texto, marca de sua integração ao fantástico mais legítimo, acompanhando-se, outra vez, a tipologia proposta pelo pesquisador búlgaro.

É o estranho que assinala de modo mais impactante a obra, pois há uma transformação nos acontecimentos, sem que os agentes se visibilizem. Baltazar funda uma companhia com o apoio de investidores vindos de fora, motivados pela ação empreendedora do Dr. Marcondes e de seu filho, Felipe. Até esse ponto da narrativa, as identidades são registradas de modo claro e evidente. Na sequência, porém, Baltazar é vítima de uma sublevação, um "golpe», como a qualifica o narrador, quando «muita gente ligada a tio Baltazar foi demitida em duas ou três penadas» (p. 29). Os autores do ato ilegítimo não são, contudo, nomeados, assim como não são identificados os responsáveis pelas várias proibiçôes que se apresentam no cotidiano de Taitara. Para falar delas, o narrador utiliza a terceira pessoa, referindo-se à Companhia, como em «A Companhia baixou novas proibiçôes». Ou então cita-as por intermédio das palavras de seu pai ou do relato da reação das pessoas.

É o apagamento da identidade do principal agente, no contexto da sociedade de Taitara, que determina a emergência do estranho. Um poder anônimo tornase absoluto, e qualquer resistência ou oposição é severamente punida, já que a autoridade está ancorada nas forças econômica e policial, por meio de fiscais implacáveis e, simultaneamente, temerosos das açôes da tirania vigente.

Taitara converte-se em um cárcere — «retidos em casa, ignorando o que se passava lá fora, vivíamos praticamente como prisioneiros» (p. 70)—, estando sua população afastada do mundo — «com isso ficamos isolados do mundo, gente de fora não ia querer entrar sabendo que não podia sair» (p. 119)—, o que justifica a eleição da alternativa restante: a fuga pela fantasia, traduzida pelos homens-pássaros, que sinalizam ao mesmo tempo liberdade e escapismo.

Obra publicada em 1972, Sombras de reis barbudos foi imediatamente entendida como alegoria da ditadura militar que governava o Brasil desde abril de 1964, após o golpe que derrubara o presidente João Goulart (1919-1976), no poder desde 1961, na sequência do conturbado episódio político decorrente da renúncia de Jânio Quadros (1917-1992), de quem fora vice-presidente. Vários acontecimentos justificavam o cotejo entre os fatos históricos e sua representação pelo romance: 
- Baltazar, como Goulart, havia sido derrubado por um golpe (observe-se certo paralelismo fônico entre os nomes dessas duas figuras).

- Os golpistas tomaram o poder após a derrubada do presidente, que se exilou no Exterior.

- $\quad$ E Estado militar agiu de modo repressivo, recorrendo à violência, à censura e à perseguição política, de que resultaram mortes, desaparecimentos e exílios voluntários.

- O governo, instalado em 1964, tornou-se crescentemente mais autoritário, não se vislumbrando, no começo da década seguinte, qualquer indício de retomada das liberdades civis. Essas somente apareceram no horizonte do Estado após a posse de Ernesto Geisel (1907-1996), que, presidente entre 1974 e 1979, prometeu uma abertura «ampla, geral e irrestrita», concretizada, porém, apenas depois dos anos 1980.

Essas associaçóes são sutis no desenvolvimento da obra, mas não deixam de transparecer. A mais evidente ocorre quando se registra, em um dos tantos muros que dividem a cidade, o protesto verbal das pessoas, descontentes com o regime: «abaixo a cia» (p. 56), expressão indicativa da participação do governo norte-americano e de sua principal agência internacional de espionagem nos negócios da vida brasileira.

Interpretada a obra sob esse aspecto, o estranho toma outro significado, tornando-se a ferramenta de denúncia da situação anormal experimentada pela sociedade e por sua população. O estranho não é da ordem do fantástico, mas não é menos assustador e apavorante por efeito de ações autoritárias, marcadas pelo coação e supressão da liberdade, capazes de eliminarem o desejo de viver por parte dos seres humanos.

Considerando a recepção de que foi objeto enquanto alegoria do Brasil na passagem da década de 60 para a de 70 no século xix, justificar-se-ia a permanência de Sombras de reis barbudos no horizonte de leitura do público brasileiro na atualidade, época de vigência da democracia?

Cabe observar que, superadas as condições originais de sua recepção, mais se evidencia o papel de Sombras de reis barbudos enquanto alegoria política, conforme evidenciam algumas cenas. Em uma delas, o pai de $\mathrm{Lu}$, aliciado pelas forças da repressão, chama a atenção para a importância do uniforme — a «farda»— para 
o exercício de sua função, ainda que aquela indumentária, de tipo militar, não constituísse um de seus pré-requisitos:

Um dia meu pai chegou muito alegre, satisfeito mesmo da vida, criei coragem e fiz essa pergunta. Ele riu e respondeu:

— Sou obrigado não, Lu. Essa farda eu mesmo inventei. Impóe mais respeito. —Girou para mostrar a farda. - Bonita, não? Você precisa ver como a cambada me trata. Só faltam se mijar. Um dia vamos dar uma volta juntos para você ver. (p. 32).

O controle absoluto e injustificado sobre todas as atividades da população é outra marca dos regimes autoritários representados no livro. Assim, Lu e sua mãe, que, para sobreviver economicamente após a prisão do pai, mantêm uma pequena horta no quintal de sua casa, são obrigados a registrar toda e qualquer plantaçáo encontrável no local. Da mesma maneira, a construção de muros que dificultam o deslocamento das pessoas pela cidade traduz o esforço em impedir o livre trânsito dos cidadáos e a comunicação entre eles. Vigora igualmente a iniciativa mais característica dos regimes totalitários: a construção de prédios para aprisionar indivíduos e, ao mesmo tempo, sujeitá-los a experiências científicas, transformados em cobaias de laboratórios, experiência de que os campos de concentração nazistas são o exemplo mais notório:

A Companhia estava construindo um prédio grande do outro lado do rio, diziam que era para instalar um laboratório. Comecei por aí.

— Laboratório? Quem disse que é laboratório? —ele perguntou.

- Ouvi dizer.

— Laboratório. Vocês cá fora não sabem de nada mesmo, heim? Laboratório. —Sorriu, sacudindo a cabeça para a nossa ignorância.

—É o que estão dizendo — resmunguei desapontado.

— Até que não ficava muito esquisito chamar cadeia de laboratório. (p. 72-73).

Sob esse aspecto, Sombras de reis barbudos acompanha a tradição representada por romances como 1984, de George Orwell (1903-1950), ilustrativos da denúncia das formas de dominação da sociedade por um organismo totalitário, indiferente aos destinos humanos e focado tão-somente na sua própria manutenção e expansão. 
Sombras de reis barbudos não narra apenas a trajetória política e econômica de Taitara sob o domínio, originalmente benéfico, depois despótico, da Companhia. O narrador, Lu, dá conta de seu percurso existencial, marcado pela chegada, à cidade, de seu tio, Baltazar, que, como o mago com o qual compartilha o nome, traz presentes e boas notícias à família e à cidade. Nesse início da história, Lu, então com onze anos de idade, é admirador do tio bon vivant e vibra com a prenda recebida, «um relógio dourado com pulseira dourada», «relógio de verdade» (p. 11). Mais adiante, a admiração estende-se a todos habitantes da cidade, sacralizando o fundador da Companhia e responsável pelo progresso de Taitara: «dar uma volta com tio Baltazar pela cidade era como andar na companhia de um deus ou de um santo, as pessoas só faltavam ajoelhar quando passávamos» (p. 20).

Esse tio será, posteriormente, deposto e exilado. Lu reencontra-o quando o visita no local onde agora reside. Ao chegar, descobre que Baltazar está muito doente, razão porque o rapaz não recebe atenção imediatamente por parte dos moradores da casa. A espera é longa, e Lu adormece, sonhando com o tio, na seguinte circunstância:

Tio Baltazar passava muito bem. A reuniáo era uma festa para comemorar a torre que ele acabava de construir, obra nunca vista e muito importante encomendada por uma comissão de reis barbudos. Como prêmio tio Baltazar ia ser nomeado rei também, aquela gente toda estava ali para ajudá-lo a experimentar a roupa, a coroa e a barba postiça que ele ia usar enquanto náo crescesse a verdadeira. (p. 86).

O sonho de Lu antecipa a festa dos reis barbudos prometida ao final da narrativa pelo professor que elucida o mistério dos homens-pássaros. O caráter benfazejo dessas figuras atravessa o romance, já que é o generoso Baltazar quem encarna um deles. Se estão nas sombras, como sugere o título do livro, promete-se sua apariçáo, garantindo o início de um novo tempo, à moda dos magos de quem o tio de Lu importa a denominação. Afinal, é ele, ao contrário dos proprietários da Companhia, a personagem masculina adulta nomeada (exceção feita a Horácio, pai de Lu), sinal de que sua identidade é motivada e simbólica.

Baltazar aparece, assim, na condição do liberador, herói com propriedades mágicas, sugeridas por seu nome. Mas a liberação, para Lu, não depende apenas da ação dele, nem fica condicionada à questão política, já que o garoto, tal qual Charles de Crozon, em As crônicas do sochantre, passa por um crescimento e um 
amadurecimento, processo suscitado pela presença de uma figura feminina — tia Dulce, a esposa de Baltazar.

Ao visitar o doente Baltazar, Lu, não mais o adolescente de onze anos, se depara com outra tia Dulce, a que escolhe o rapaz para parceiro sexual, embora ele nem sempre perceba conscientemente os acontecimentos: «Eu fiquei molhado de suor, com a cabeça latejando, sem entender nada daquilo» (p. 88). Mesmo assim, aceita o jogo proposto, deixando-se dominar pela mulher mais experiente.

É importante destacar que as duas situaçôes —o sonho com Baltazar sendo coroado rei; o desabrochar da vida sexual de Lu— dão-se no mesmo local, longe de Taitara, e na mesma noite. O rapaz depara-se com duas revelações, que abrem caminho para o adulto que ele poderá vir a ser, cenas correspondentes, portanto, ao ritual de passagem de um adolescente na direção da maturidade. Sob esse aspecto, o relógio de ouro, com que Lu fora presenteado por Baltazar, adquire caráter simbólico, ao medir o tempo pessoal da personagem, e até profético, pois o doador da prenda é a mesma figura que colabora para o processo intelectual e evolutivo do moço.

As duas situaçóes narradas por ocasião da visita ao tio concluem esse processo. A primeira posiciona-se no âmbito da fantasia — trata-se de um sonho-, a segunda, no da vivência, estabelecendo-se entre elas uma equivalência, tanto mais forte porque Dulce participa das duas: é a rainha por ocasião da festa de coroação de Baltazar — «Tia Dulce passou por mim vestida de rainha e pintando as unhas com esmalte, o cabelo comprido voando para trás e largando um perfume de rainha» (p. 86) - e a amante por ocasião do encontro entre com o narrador. Assim, Lu ocupa o posto do tio enquanto parceiro masculino, habilitando-se a substituí-lo, quando o processo de aperfeiçoamento se complementar. Por essa razão, é também $\mathrm{Lu}$ — sob esse aspecto assumindo a função sugerida por seu nome, a de Lucas, o evangelista- quem pode narrar a história, conferindo seu significado, primeiro passo para a liberação — interna e externa — a que a novela almeja.

Tal como no universo de Charles de Crozon, não são mais os mortos que imperam, mas jovens, portadores de uma mensagem libertadora, ainda que, para chegar a essa condiçáo, tenham de abrir mão da infância, naquilo que ela tem de ingênua e pueril. 


\section{4. À MODA DA EDIÇÃO ESPANHOLA DAS CRÔNICAS, UM EPÍ- LOGO. OU: OS MORTOS NÁO ESPERAM}

Um ano antes de José J. Veiga publicar Sombras de reis barbudos, portanto, no mesmo contexto político que embasou aquele livro, Erico Verissimo (1905-1975) lançou Incidente em Antares, o derradeiro romance desse escritor.

A trama do livro divide-se em duas partes, sendo a segunda a mais representativa da obra. Dela participam pessoas que, recentemente falecidas, não são enterradas, porque os coveiros de Antares, município imaginado por Erico Verissimo situado na fronteira do Rio Grande do Sul, declararam greve. Insepultos, os cadáveres dirigem-se para a praça central da cidade, exigindo a execução de suas exéquias. Diante da plateia aglomerada no local, eles, sem qualquer pudor ou censura, procedem a graves denúncias: o comportamento sem ética dos parentes, mesmo os mais próximos, o emprego da tortura pela polícia, a prática de adultérios, fraudes e falcatruas. Vem à tona a podridão da sociedade, de ordem moral, política e ideológica, mais forte e mais deplorável que a corrupção física dos mortos responsáveis pelas acusaçôes.

Tal como na obra de Álvaro Cunqueiro, no livro de Erico Verissimo os insepultos sinalizam o desregramento da sociedade, assim como a decomposição da justiça. A desordem motiva o recurso ao fantástico, já que os mecanismos próprios à literatura realista parecem não bastar. Por isso, o deflagrar do estranho, que toma duplo sentido: de um lado, o evento narrado, que náo se enquadra na normalidade do cotidiano; de outro, o próprio cotidiano, que contradiz o que se espera dele, se examinado desde o prisma dos valores e princípios formulados por uma comunidade. Estranho e assustador é o que ocorreu com os preceitos éticos, desfigurados e desonrados, razão porque os escritores aqui examinados - Cunqueiro, Veiga e Verissimo- valeram-se do gênero que provavelmente melhor deu conta de sua representação. Graças a esse trabalho, a literatura fantástica garantiu sua vitalidade, sem abrir mão de sua originalidade e legitimidade. 